Detail Recon Image において著しい粒状性の低下が認 められ，必ずしも画質的に向上するとは言えない.しか し高密度, 高コントラスト物質の微細構造の描出には有 用であった。

\section{3. 伝達情報量によるスライス厚の評価}

岡山大学医学部附属病院中央放射線部 ○延原采太郎・小橋利美・小栗宣博 大川義弘 - 井上龍也・稲村圭司 江草具視・三上泰隆・松島紀志夫 岡山大学医学部附属診療放射線技師学校 吉団 彰

【目的〕 partial volune 現象を考慮に入机た実測值 $10.0 \mathrm{~mm}, 5.3 \mathrm{~mm}, 3.7 \mathrm{~mm}$ の各 slice 厚の評価を, 伝達 情報量を用いて，種々の\% contrastについて行った.

〔結果〕 partial volume 現象を生じない場合は，当然 のととながら, slice 厚が厚い程，伝達情報量は多くなっ た. partial volume 現象が生じた場合，今回の方法では， 2. $0 \%$ contrast 程度以下において約 $7 \mathrm{~mm}$ 厚以下の物体 を見る場合は， $10 \mathrm{~mm}$ slice より公称 $5 \mathrm{~mm}$ slice, 約 4 $\mathrm{mm}$ 厚以下の場合は公称 $2 \mathrm{~mm}$ の方が有効であるという 結果が得られた。また，9.5\%において，1 $\mathrm{mm}$ 或いは 2 $\mathrm{mm}$ という溥い物体を目的とする場合, 薄い slice 厚ほ ど有効であるという結果が得られた。

\section{座長集約}

村上 浩（徳島県立中央病院）

41 では吸収差の少ない物質の分解能は，予想に反して 撮影管電圧を低くすると低コントラスト分解能が低下す ると報告した。通常使用の高電圧 $(120 \mathrm{kV})$ と比較する 場合, $\mathrm{CT}$ 值, $\mathrm{SD}$ 等の問題むあると思われるが，もう少 し電庄を低くするか, スライス厚等での検討を望みた 认.

42では Target Image の有用性について, 空間分解能, 粒状性の面から検討した結果，空間分解能は多少向上す るが粒状性の低下のため，画質的には必ずしも向上する とは言えない，しかしCT 值の差が大きく，密度の高い 部位の微細構造の描出には有効で，また，拡大に使用す る場合は Normal Image より有效であると報告した。

43では partial volume の現象を考慮した伝達情報量に よるスライスの評価を報告した。

CT 装置の普及岋めざましいものがある. 今後共装置 の既製の使用法にとらわれるてとなく，使用法の搪大を 衫らて検討を重ねていただきたい.

\section{Bucky 撮影時における振動の影響について}

愛媛大学医学部附属病院
○高須賀章・吉本政弘・上田幸介 名本繁樹・伊達卓二・川上寿昭 国立療養所愛媛病院 堀内俊三

〔目的〕立位ブッキ撮影台は、ブッキ移動時に振動を 発生し，画質を低下させる原因の一つとなっている。 そ こで振動状態を測定すると同時にテストチャートを用い て MTF を測定し，画質への影響について検討した.

【結果】ブッキ枠とカセッテ受けの振動の影響を比較 するとカセッテ受けへの影響が大であった・ブッキ静止 時とブッキ移動時で固定を強化した場合，強化しない場 合のMTFを比較すると固定を強化することによりMTF の向上が見られ振動による影響を減少させているてとが 判った。 また撮影時間 $(0.032$ 秒， 0.063 秒， 0.13 秒) を 変化させブッキ静止時との MTFを比較すると短時間撮 影の方が振動による影響が少なかった。

現在X線写真の鮮鋭度を評価する方法としては, MTF が一般的であるが, MTF による画像評価と読影者（医 者）側の写真評価が必ずしも一致しない事はよく経験す る. MTFの画像評価において,デー夕収集は物理的（機 械的）であるのに対して読影者側のそれは感覚 (視覚) 的である，そてでての両者をできる限り一致させる必要 があると考え，胸部㝍真を例として検討を加え報告し t.

\section{6. 二元配置法による画像評価}

岡山大学医学部附属病院中央放射線部 ○門久繁文・永谷伊佐雄・若狭弘之 田原誠司・森岡泰樹・中桐義忠 服部綾雄・三上泰隆・松島紀志夫

一般に近似した特性值を比較する場合，同一条件下で 繰り返えし実験を行った場合てさえ，異った值を示すし とをしばしば経験する。

ての事は，実験誤差を考慮しないでの判定ではなかる うかと考える。

そてで, 今回われわれは有意評価の 1 方法として統計 的手法を導入し，象験誤差の表示，しれを含んだ状態て の有意差の検定，また，母平均の区間推定を試みた。

ての方法は，近似した特性值の有意差の検定において， 実験誤差を考慮した評価となり有効であると考える.

\section{7. 被写体組成配列の差による画質の比較} 高知医科大学医学部附属病院放射線部 ○森田尚亨 $\cdot$ 遠山坦彦・久保嘉彦 山本 登・下司博之・赤木直樹 沖野和弘 $\cdot$ 皇山高志 $\cdot$ 田和 原坂仁詞・横田典和 